tumours, such as the use of thermosensitive and radiosensitive endoscopic probes and fluorescence bronchoscopy with haematoporphyrin as a tumour marker, ${ }^{12}$ are applicable only to individual cases and have no place in any screening programme. A recent suggestion ${ }^{13}$ that a below-average dietary intake of provitamin A (carotene) may be associated with an increased incidence of lung cancer is of epidemiological interest but is almost certainly of no practical value in identifying high-risk population groups.

Probably the best we can offer potential victims of lung cancer at present is annual screening by sputum cytology and chest radiography, and even that would be time consuming and expensive. Perhaps some day a reliable serological test for detecting early lung cancer will be developed. For the time being, the only effective means at our disposal to reduce the death rate from this disease is to persuade people not to smoke.

IAN W B GRANT

Consultant Physician

Respiratory Unit,

Northern General Hospital,

Edinburgh EH5 2DQ

1 Nash FA, Morgan JM, Tomkins JG. South London Lung Cancer Survey. Br Med f 1968;ii:715-21.

2 Jackman RJ, Good CA, Clagett OT, et al. Survival rates in peripheral bronchogenic carcinoma up to four centimetres in diameter presenting as solitary pulmonary nodules. F Thorac Cardiovasc Surg 1969;57:1-8.

3 Steele JD, Kleitsch WP, Dunn JE jun, et al. Survival in males with bronchogenic carcinomas resected as asymptomatic solitary pulmonary nodules. Ann Thorac Surg 1966;2:368-76.

4 Buell PE. The importance of tumor size in prognosis for resected bronchogenic carcinoma. F Surg Oncol $1971 ; 3: 539-51$.

${ }^{5}$ Matthews MJ. Morphology of lung cancer. Semin Oncol 1974;1:175-82.

6 Cohen MH. Signs and symptoms of bronchogenic carcinoma. Semin Oncol $1974 ; 1: 183-9$.

${ }^{7}$ Medical Research Council Lung Cancer Working Party. Radiotherapy alone or with chemotherapy in the treatment of small-cell carcinoma of the lung. Br $\mathcal{F}$ Cancer 1979;40:1-10.

${ }^{8}$ Johnson RE, Brereton HD, Kent CH. Small-cell carcinoma of the lung: attempt to remedy causes of past therapeutic failure. Lancet 1976 ;ii: 289-91.

9 Greco FA, Oldham RK. Current concepts in cancer. Small-cell lung cancer. N Engl f Med 1979;301:355-7, 8.

10 Fontana RS, Sanderson DR, Woolner LB, et al. The Mayo Lung Project for early detection and localisation of bronchogenic carcinoma: a status report. Chest 1975;67:511-22.

11 Woolner LB, Fontana RS, Sanderson DR, et al. Mayo Lung Project. Evaluation of lung cancer screening through December 1979. Mayo Clin Proc $1981 ; 56: 544-55$

12 Kinsey JH, Cortese DA, Sanderson DR. Detection of haematoporphyrin fluorescence during fibreoptic bronchoscopy to localise early bronchogenic carcinoma. Mayo Clin Proc 1978;53:594-600.

13 Shekelle RB, Lepper M, Liu S, et al. Dietary vitamin A and risk of cancer in the Western Electric study. Lancet 1981 ;ii:1185-9, 90.

\section{Cardiac catheterisation: here today, where tomorrow?}

Among the most crucial developments in modern cardiology was the advent of cardiac catheterisation during the second world war. The whole edifice of cardiac surgery-for valve disease, congenital lesions, relief of coronary stenoses, and more recently the management of arrhythmias-is built on the proper application of this procedure. Cardiac physiologists had long been familiar with catheterisation in animals, but the feasibility of the procedure in man was first shown by the late Werner Forssmann on himself in 1929. While his seniors discouraged Forssmann from further work (and indeed his subsequent career lay elsewhere) his important contribution was commemorated at the Einthoven meeting in Leiden in November $1979 .^{1}$

Another decade passed before other workers exploited Forssmann's technique and adapted and refined it to produce information of physiological and clinical importance. The record of the Einthoven meeting reminds us that, while Cournand in New York and, a little later, McMichael in London at Hammersmith Hospital laid the foundations of Anglo-American research, Lenègre and Maurice, cut off from knowledge of these developments during the occupation of France, independently undertook similar work. Indeed, despite grave shortages, they went even further and made the first intracavitary recordings of cardiac potentials.

So much has cardiac catheterisation influenced practice, especially since the development of coronary arteriography, that training in the technique has sometimes appeared to dominate postgraduate education in cardiology. Its universal application has now been questioned in a paper from the Brompton Hospital in which the need for routine catheterisation before valve replacement is discussed. ${ }^{2}$ Back in $1978 \mathrm{St}$ John Sutton and his colleagues delayed the decision to perform cardiac catheterisation in patients with valvular disease until they had also assessed them by non-invasive means. This led to the performance of 184 operations without prior cardiac catheterisation, elective preoperative catheterisation being performed in another 59 patients. While similar observations have been made individually elsewhere, the great strength of this paper ${ }^{2}$ is that it shows that the results of operation were identical irrespective of whether catheterisation had been performed. The surgeons found no unexpected lesions at operation, and during two years of follow-up no uncorrected valve lesions became apparent in the patients who had not undergone preoperative catheterisation.

In this series St John Sutton and his colleagues used Mmode echocardiography extensively to assess valve lesions and were able to show how reliable the method can be. Others have recently used $\mathrm{M}$-mode recordings to estimate the pulmonary artery wedge pressure and believe that it is as useful as phonocardiography in this respect. ${ }^{3}$ Two-dimensional echocardiography and radionuclide scanning are also more widely available. As a result most patients with valve disease referred for possible operation to regional cardiac centres can be fully assessed nowadays without routine catheterisation-and the diagnostic service can now be extended beyond the main cardiological centres. ${ }^{4}$ But where complications are suspected or where additional coronary artery disease might be present and need operative treatment catheterisation will continue to be required.

What about disorders other than valve lesions? Twodimensional echocardiography has an increasingly important role in defining congenital cardiac lesions ${ }^{5}$ and in many cases will make cardiac catheterisation unnecessary, though surveys will need to be as extensive as the one concerned with valve lesions $^{2}$ before final answers can be given for the various congenital lesions. Coronary arteriography will continue to play the crucial part in decision making about coronary artery bypass grafting, and the debate here is of a different order. St John Sutton and his colleagues do, however, give us important guidance. Cardiologists need to remember the resources required for routine catheterisation for valve disease and the benefits that may be achieved from their more logical application. For Richard Bing ${ }^{6}$ in 1946 the advent of the cardiac catheter "was a beautiful time, because all pioneering when done in the right environment is exciting as long as it does not become routine." 
Whenever doubt exists, catheterisation will, of course, be required to corroborate or disprove the assessment made by non-invasive means; and we must remember that the latter could not have been contemplated without the pioneering work of Claude Bernard and his successors in animals and of Forssmann and those who followed him in man.

\section{DENNIS KRIKLER}

Consultant Cardiologist,

Royal Postgraduate Medical School, London W12 0HS

${ }^{1}$ Snellen HA, Dunning AJ, Arntzenius AC, eds. History of perspectives of cardiology: catheterization, angiography, surgery and concepts of circular control. The Hague: Leiden University Press, 1981.

${ }^{2}$ Sutton MG StJ, Sutton M StJ, Oldershaw P, et al. Valve replacement without preoperative cardiac catheterization. N Engl f Med 1981;305: 1233-8.

${ }^{3}$ Askenazi J, Koenigsberg DI, Ziegler JH, Lesch M. Echocardiographic estimates of pulmonary artery wedge pressure. $N$ Engl F Med $1981 ; 305$ : 1566-8.

4 Chamberlain DA, Goodwin JF, Emanuel RW, Bailey LG. Career prospects in cardiology in England and Wales. Survey of 15 health regions. Br Heart $\mathcal{F} 1981 ; 45: 460-3$.

${ }^{5}$ Smallhorn JF, Tommasini G, Macartney FJ. Detection and assessment of straddling and overriding atrioventricular valves by two dimensional echocardiography, Br Heart $71981 ; 46: 254-62$.

${ }^{6}$ Bing RJ. Personal memories of cardiac catheterization and metabolism of the heart. In: Snellen HA, Dunning AJ, Arntzenius AC, eds. History of perspectives of cardiology: catheterization, angiography, surgery and concepts of circular control. The Hague: Leiden University Press, 1981: 43-5.

\section{Contact tracing}

Tracing contacts of patients with sexually transmitted diseases plays a vital part in their control. Sadly, however, in the past the methods used to trace contacts were both heavy handed and unsuccessful. The Contagious Diseases Acts of 1864 and 1866 allowed for the compulsory registration and admission to hospital of women "judged" by the police to be prostitutes; and under the notorious Defence Regulation 33B, introduced in 1942, a compulsory medical examination could be performed on any individual (invariably a woman) named by at least two others as a possible source of infection. Sense prevailed, and after the second world war the tracing of sexual contacts became non-authoritarian and informal.

Nevertheless, since the inception of the National Health Service the authorities have been slow to recognise the need for specially trained individuals to carry out contact tracing. Initially this work was performed by doctors, often ineffectively ${ }^{12}$ and rarely by trained staff fully integrated into the clinic. ${ }^{3}$ The pattern is different now : a recent survey in England and Wales showed that contact tracing was performed by designated non-medical personnel in $77 \%$ of clinics, ${ }^{4}$ but that in only half of these clinics was someone specifically employed for contact tracing. In the remainder the duties were carried out by nursing staff, already busy, or by health visitors, who either attended clinic sessions as well as carrying out general health visitor duties or did not attend sessions but could be called upon to do so.

Even though more clinics have acquired contact tracing facilities, the ideal is still far away: all clinics should eventually employ staff specifically designated for this task. Contact tracing should, indeed, be recognised as an integral part of the management and control of sexually transmitted diseases. Interviewing these patients requires tact, sensitivity, and special communication skills; these skills need to be identified and appropriate training programmes created to teach them.
Surprisingly, these tasks have not been tackled up to now and contact tracers have had no common, if any, training. The recent Handbook on Contact Tracing in Sexually Transmitted Diseases ${ }^{5}$ has analysed (for the first time) the process of contact tracing and by implication the types of skills and training required. The Department of Health and Social Security has responded quickly to this publication by designing and organising a series of one-week training programmes, the first of which was held in February in Harrogate. In time all those in post should be able to attend one of these courses, and a BTH (been to Harrogate) will become an essential additional qualification for those practising contact tracing. Admirable though this development is, attendance at a one-week course may hardly be seen as adequate training. No co-ordinated and planned basic qualifying course exists for those entering contact tracing, and such a training programme should be the next priority.

The final problem that needs addressing is the $14 \%$ annual turnover of contact tracers. Even though $60 \%$ of contact tracers have a nursing background, this qualification should not be a prerequisite for entry. Encouraging recruitment of individuals from varied backgrounds, specifically trained to carry out contact tracing, may help to slow the turnover. Job satisfaction is crucial. The current work of the contact tracer is too limited and ways need to be found to extend this. For example, health education is important in controlling the sexually transmitted diseases. Some contact tracers see this as part of their job. Certainly this need should be recognised as should the part that contact tracers can play in lecturing within the community, particularly in schools (or preparing teachers to do so). But changes of that kind cannot happen until individuals are trained in the teaching of young people-as well as the other skills required to carry out the essential job of contact tracing.

$\mathrm{M}$ W ADLER

Professor of Genitourinary Medicine

Middlesex Hospital Medical School,

London WIN 8AA

${ }^{1}$ Haworth MC, Nicol CS. Tracing the contacts of male patients with acute gonorrhoea. Br 7 Vener Dis $1954 ; 30: 36-7$.

${ }^{2}$ Dunlop EMC. Epidemiology of gonorrhoea. Certain aspects of control of the disease in women with particular reference to contact tracing. $\mathrm{Br} \mathcal{F}$ Vener Dis 1963;39:109-12.

3 Wigfield AS. 27 years of uninterrupted contact tracing. The "Tyneside scheme." Br 7 Vener Dis 1972;48:37-50.

Health Education Council. Project investigating the job requirements and training of health workers in special clinics. Report. London: HEC, 1977.

${ }^{5}$ Health Education Council, Department of Health and Social Security. Handbook on contact tracing in sexually transmitted diseases. London: HEC, 1980.

\section{Therapeutic potential of cannabinoids}

Extracts of the plant Cannabis sativa have been used for medicinal purposes for several-thousand years. The major active psychotropic principle, delta-9-tetrahydrocannabinol, produces prominent effects on the central nervous and cardiovascular systems. The actions of tetrahydrocannabinol include euphoria, drowsiness, short-term impairment of memory, temporal disorientation, confusion, and depersonalisation. Higher doses of tetrahydrocannabinol result in hallucinations and delusions, and anxiety may replace euphoria. Effects on other systems include conjunctival suffusion, tachycardia, 